Artigos 



\title{
O golpe civil-militar de 1961: Crítica a uma explicação hegemônica
}

\author{
Daniel de Mendonça*
}

\section{Resumo}

O presente artigo tem como objetivo apresentar uma visão crítica em relação à interpretação hegemônica a qual defende que, em 1961, após a renúncia de Jânio Quadros, ocorreu uma frustrada tentativa de golpe militar, uma vez que João Goulart conseguiu assumir, de fato, a Presidência. Neste trabalho, argumenta-se que ocorreu, na verdade, um golpe civil-militar com a participação do Congresso Nacional Brasileiro.

Palavras-chave: Golpe de 1961, João Goulart, Congresso Nacional Brasileiro

\section{Introdução}

$\mathrm{O}$ s episódios que antecederam a posse de João Goulart na Presidência da República, em sete de setembro de 1961, revestem-se de uma certeza teórica hegemônica no âmbito das ciências sociais, a qual peremptoriamente afirma: a combinação entre a instituição do sistema parlamentarista de governo e a posse de Jango evitaram, ao mesmo tempo, um golpe militar e possibilitaram a manutenção do regime democrático que viria somente a ser atingido fatalmente em março de 1964. Tendo em vista essa certeza inicial, forjada, como se verá neste trabalho, a partir de um pacto entre elites políticas no período em questão, praticamente todos os analistas e cientistas sociais que se debruçaram sobre o tema concordam, muitas vezes

* Doutor em Ciência Política pela Universidade Federal do Rio Grande do Sul (UFRGS). Professor no Instituto de Sociologia e Política e no Mestrado em Ciências Sociais da Universidade Federal de Pelotas (UFPel). 
de forma acrítica e até mesmo desinteressada, com o sentido dado ao desfecho desta crise. Assim, formou-se uma idéia-força, tornou-se óbvio dizer que o resultado do que ocorreu entre vinte e cinco de agosto e sete de setembro de 1961 foi uma vitória legalista contra um golpe militar em curso. Nada mais óbvio não fosse a verdade.

Neste artigo, contrariando essa interpretação hegemônica, buscar-se-á construir uma argumentação em defesa da idéia de que a combinação da posse de Goulart e a instituição do parlamentarismo resultou, na verdade, num bem-sucedido golpe de Estado civil-militar. Para subsidiar a defesa desse que será o argumento central, o presente trabalho está dividido nas seguintes seções abaixo descritas.

Na primeira seção, será caracterizada a dita interpretação hegemônica a partir de posições assumidas por alguns autores. Na segunda seção, serão apresentados os principais argumentos das duas posições políticas antagônicas que se formaram no período que serão chamadas respectivamente de "discurso militar" e de "discurso legalista”. Nas terceira e quarta seções, a crise sucessória de Jânio Quadros será significada a partir das discussões entre os deputados federais. Por fim, será apresentado o argumento central deste paper, o qual indica que a solução encontrada para o impasse político em questão constituiu-se num bem-sucedido golpe civil-militar.

Neste trabalho, foram criadas as categorias "diagnósticos de desordem" e "soluções de ordem", que auxiliarão na compreensão dos discursos antagonicamente constituídos, ou seja, o discurso militar e o discurso legalista. Os "diagnósticos de desordem" caracterizam os sentidos negativos que esses diferentes grupos políticos significavam sobre cada um dos momentos escolhidos. Em outras palavras, representavam as causas das crises identificadas pelos diferentes discursos concorrentes no episódio a ser estudado. Já as "soluções de ordem" eram as respostas que ambos os discursos antagônicos buscavam para solucionar a crise. Nesse sentido, nas seções a seguir, buscar-se-á conhecer os "diagnósticos de desordem" e "soluções de ordem", respectivamente, do discurso militar e do discurso legalista. 


\section{A reprodução hegemônica da tese do golpe militar frustrado}

O principal evento ocorrido na década de 1960, estudado pelos cientistas sociais brasileiros, foi efetivamente o golpe militar que teve lugar em 1964. Nesse sentido, respeitadas análises foram empreendidas, buscando, sobretudo, desvendar aqueles acontecimentos que solaparam o então frágil regime democrático instituído a partir de 1945. Essa necessidade de explicação do golpe propriamente dito pode ter sido uma das causas principais para a pequena atenção dada à crise resultante da renúncia de Jânio Quadros. Contudo, existem razões para se crer que a pouca importância dada aos acontecimentos de 1961 pode ter, inclusive, impedido uma compreensão mais acurada do próprio golpe de 1964, como buscar-se-á elucidar a seguir.

Antes disso, nesta seção, será explicitado o discurso hegemônico constante nas ciências sociais no Brasil, o qual reduz os acontecimentos que redundaram na ascensão de Jango na Presidência, sob a égide de um sistema parlamentar de governo, como um bemsucedido impedimento de um então golpe militar em curso. Desta forma, serão apresentados alguns entendimentos de analistas do período, os quais são unânimes em conceber a posse de Jango como resultado de uma solução política que evitou o golpe intentado pelos ministros militares de Quadros. Neste sentido, será tomada particularmente a análise de Argelina Figueiredo como caso exemplar deste entendimento hegemônico que será aqui criticado.

Assim, inicialmente, René Dreifuss (1981) entende que após a renúncia de Jânio Quadros o que ocorreu foi uma "mal preparada manobra militar" para impedir a posse de Goulart, que foi barrada a partir de um bloco de poder popular. Apesar de admitir que o resultado da crise, ou seja, a combinação de um sistema parlamentarista com Jango na Presidência tenha efetivamente limitado o poder de João Goulart, Dreifuss é categórico na caracterização do "fiasco do golpe de 1961" (1981, p. 130).

Wanderley Guilherme dos Santos (2003) entende como suficiente e necessário o fato de a ascensão de Goulart na Presidência ser um indício de que não houve uma manobra bem-sucedida entre 
final de agosto e início de setembro de 1961. Segundo o autor, "em fins de 1961, a oposição militar não fora suficientemente forte para impedir que João Goulart ocupasse a Presidência da República após a renúncia de Jânio Quadros” (2003, p. 170).

Já a análise de Thomas Skidmore (1967) enfatiza claramente que o que ocorreu em 1961 foi uma tentativa fracassada de golpe. Segundo este autor, a oposição militar fracassou somente porque "a oficialidade estava dividida e porque a opinião civil de centro preferia uma solução 'legal' para a crise” (1967, p. 216). É interessante destacar que a solução "legal" apontada por Skidmore está entre aspas, ou seja, trata-se, na verdade, como parece indicar o autor, de uma duvidosa legalidade.

Para além das posições expressas acima, é particularmente interessante a construída por Argelina Figueiredo (1993). O discurso da autora acerca das causas do golpe militar de março de 1964, centrado, sobretudo, na "conduta estratégica de atores políticos em situações históricas concretas enfatizando interesses e percepções e formulando os problemas em termos de possibilidades e escolhas" (1993, p. 29), possibilita ao leitor ter uma idéia muito profícua dos interesses e das ações dos vários atores que disputaram politicamente naquele conturbado momento da vida política nacional.

Contudo, a análise de Figueiredo apresenta um ponto crítico importante, localizado no capítulo primeiro do seu trabalho, o qual tem a ver com o desfecho da crise da renúncia de Jânio Quadros. Nesse sentido, serão aqui tomados alguns excertos do seu texto para ilustrar melhor a sua posição e demonstrar as ambiguiidades da análise. Assim, na introdução de "Democracia ou reformas?" a autora anuncia:

No Capítulo 1 [Goulart no poder: compromisso institucional] analiso a formação de uma forte coalizão contra a tentativa dos ministros militares de impedir a posse de Goulart na presidência. Uma solução de compromisso foi alcançada com a substituição do sistema presidencialista pelo sistema parlamentarista (FIGUEIREDO, 1993, p. 31).

Tomando agora o capítulo anunciado, a autora menciona a posição da ala "legalista" das Forças Armadas, contrária ao golpe pretendido pelos ministros militares: 
Como vimos, a ala legalista das Forças Armadas discordava fortemente da intervenção unilateral dos ministros, mas compartilhava da reserva com que os ministros encaravam os pontos de vista políticos de Goulart. Por isso, embora esse grupo considerasse ilegítimo o argumento de segurança nacional objetivando impedir a posse do vice-presidente, era-lhe muito conveniente uma solução intermediária que permitisse a manutenção dos poderes constitucionais de Goulart, ao mesmo tempo em que reduzia seu poder real (idem, p. 46).

Note-se que, além de interessante para a ala "legalista" das Forças Armadas, que guardava uma série de reservas em relação a Goulart, a solução parlamentarista, que envolvia a perda quase completa do poder decisório de Jango, era também interessante para o maior partido do Congresso Nacional, o PSD:

Da parte do PSD havia duas outras razões para seu apoio ao regime parlamentarista. Em primeiro lugar, sendo o partido majoritário, ele desempenharia um papel importante na formação do gabinete. Seria, portanto, capaz de recuperar sua influência (perdida com a vitória de Quadros) sobre a administração central e as políticas do governo. Mas havia também um cálculo eleitoral: empossado presidente, Goulart, que poderia vir a ser um forte candidato presidencial em 1965, seria excluído da disputa daquela eleição (idem, p. 47).

Além de o casuístico parlamentarismo ser interessante à ala "legalista" das Forças Armadas, o era também muito vantajoso para o PSD, que ganharia "de presente" um governo perdido eleitoralmente com a vitória de Quadros em 1960. Ademais, o Ato Adicional de alteração do sistema político foi também aceito pelos ministros militares que, no início da crise, vetaram a posse de Goulart, conforme mesmo demonstra Figueiredo:

Os ministros militares impuseram duas condições para a aceitação do Ato Adicional (...). A primeira se referia à faculdade do presidente de dissolver o Congresso e promover novas eleições. (...) embora a emenda garantisse formalmente ao presidente a prerrogativa de dissolver o Congresso e promover eleições a fim de aglutinar apoio para políticas governamentais, a utilização efetiva desse mecanismo não era permitida a Goulart, pois, de acordo com o Ato Adicional, todos os mandatos legislativos em curso estavam garantidos (...). A segunda medida, também talhada para as circunstâncias específicas 
da crise daquele momento, era a inclusão da vaga cláusula de "risco para a segurança nacional" entre as condições pelas quais se poderia pedir o impeachment do presidente (idem, p. 49).

A aludida "solução de compromisso" que defende Figueiredo neste trabalho não se trata de uma verdadeira "solução de compromisso" entre as duas partes efetivamente em disputa naquele momento, ou seja, os deputados legalistas do PTB e do PSB, Brizola e a sua Cadeia da Legalidade, de um lado e, de outro lado, os ministros militares golpistas. A dita "solução de compromisso", na prática, envolveu os ministros militares, a ala "legalista" das Forças Armadas, ambos "desconfiados" de Goulart, a UDN, o PSD que contabilizava, ao final da crise e com esse desfecho, ser presenteado com sua volta ao governo. Nesta negociação, Goulart não teve escolha, teve de aceitar a imposição da "solução de compromisso". Brizola ficou completamente isolado, sem o apoio inclusive de Machado Lopes, comandante do III Exército, que também acabou aceitando a solução parlamentarista. A "solução de compromisso", dessa forma, deixou de fora a esquerda política brasileira.

No texto de Figueiredo nota-se o problema da sua defesa que a "solução de compromisso" foi uma medida política que efetivamente evitou uma "ruptura institucional". Nas palavras da autora: "formou-se, imediatamente, uma coalizão contra a ruptura institucional, incluindo tanto os grupos esquerdistas e nacionalistas que apoiavam as reformas de Goulart, quanto grupos e lideranças conservadoras" (Figueiredo, 1993, p. 38). Assim, deve-se registrar que a única coalizão que buscou evitar uma "ruptura institucional" foi aquela capitaneada por Leonel Brizola e a sua Campanha da Legalidade, que teve ainda apoio dos membros do PTB e do PSB no Congresso Nacional, a qual foi completamente alijada no final da crise, pois que seus membros não concordavam com a "solução parlamentarista", vista por eles como uma "solução de continuidade", como um "golpe branco", ou seja, uma ruptura casuística das regras do jogo promovida inicialmente pelos ministros militares e que teve a aquiescência do Congresso Nacional.

O problema de afirmar que a "solução de compromisso" evitou uma "ruptura institucional", pode ser percebido nas pas- 
sagens que serão a seguir citadas. Nesse sentido, a autora afirma: "o desenrolar dos acontecimentos (...), não favoreceu a alternativa estritamente legal, e a solução parlamentarista prevaleceu” (1993, p. 43). Em outro momento, Figueiredo observa:

A defesa de uma solução estritamente constitucional, ou seja, dar pleno poder presidencial para Goulart, permaneceu confinada a uma minoria. No Congresso, a ala esquerda do PTB e os representantes socialistas denunciaram o "golpe branco" implícito na lei que instituía o sistema parlamentarista (idem, p. 47).

Com base nas duas passagens acima transcritas, pode-se problematizar o argumento da autora. Ao longo do capítulo, ela menciona ter havido uma "solução de compromisso" para garantir a manutenção do regime democrático. Não menciona, contudo, que a "solução de compromisso" retirou plenamente da mesa de negociações do impasse justamente aqueles grupos que defendiam tão-somente a estrita manutenção da ordem democrática vigente, ou seja, a simples posse de Goulart na Presidência da República sob o regime presidencialista. Nas passagens acima, a própria autora admite que a "solução de compromisso" não foi uma "alternativa estritamente legal" ou não foi uma "solução estritamente constitucional". Por mais que o Direito possa gerar amplas exegeses sobre alterações legais de qualquer natureza, é realmente difícil, do ponto de vista jurídico, neste caso, afirmar de que a "solução de compromisso" não passou, na verdade, de um "golpe branco" contra a democracia brasileira. Assim, não existe, como busca defender Figueiredo, alternativa mais ou menos legal. Tratou-se, na verdade, de uma grosseira ruptura política, um verdadeiro golpe de Estado, como afirmava, completamente isolada, a esquerda política do período.

O problema na interpretação de Figueiredo assenta-se no fato de que a autora não considerou a hipótese de que os ministros militares tão-somente não queriam Goulart como presidente. Fora isso, eles não tinham um plano de tomada de poder, um projeto político plenamente construído de conquista do Estado. O golpe foi contingente, pois a situação política gerada pela renúncia de Quadros era também contingente, absolutamente inesperada. A autora afirma que os ministros militares buscaram uma "saída honrosa" para 
a crise política por eles gerada. Não se pode igualmente concordar com isso, pois eles próprios participaram e opinaram sobre aspectos pontuais do Ato Adicional que impôs o parlamentarismo a Goulart, que não teve alternativa a não ser a de aceitá-lo.

Contrariando o entendimento dominante acima evidenciado, o que se pretende neste artigo, portanto, é apresentar uma leitura diferente acerca dos importantes acontecimentos de 1961, os quais postulam-se aqui como fundamentais para uma melhor compreensão do que ocorreu em março de 1964. Assim, entende-se como premissa geral que se o golpe de 1961 não tivesse sido barrado com o retorno das prerrogativas presidenciais a Jango, em 1963, possivelmente o golpe de 1964 não tivesse sequer ocorrido. Desta feita, nas seções subsequientes, buscar-se-á reconstruir o caminho discursivo das posições políticas constituídas a partir da renúncia de Jânio Quadros e, assim, apresentar uma interpretação diversa da dominante acerca do resultado que combinou a Presidência de João Goulart com a instituição do sistema parlamentarista de governo.

\section{Os discursos militar e legalista: duas razões para a crise}

Nesta seção, serão demonstrados os dois posicionamentos discursivos antagônicos que centralizavam a crise da sucessão de Jânio Quadros. No primeiro momento será apresentado o discurso militar que, em linhas gerais, enunciará as razões pelas quais Jango não deveria assumir a Presidência da República. Escolheu-se o documento intitulado "Manifesto dos ministros militares", uma vez que o mesmo constitui-se no mais significativo documento produzido por esses ministros, além de ser de cunho oficial. ${ }^{1}$

1 Outros documentos acessíveis que demonstram esta posição discursiva referemse às trocas de mensagens realizadas por rádio entre o comandante do III Exército, general Machado Lopes, e o gabinete do ministro do Exército, principalmente a partir de seu chefe de gabinete, general Orlando Geisel. Tratamse de duas trocas de mensagens em 27/08/1961 e uma em 28/08/1961. Além dessas, podem ser também pesquisados outros dois documentos: o radiograma do general Cordeiro de Farias ao III Exército, em 03/09/1961, e o telegrama de Cordeiro de Farias ao general Machado Lopes, em 04/09/1961. Todos esses documentos estão disponíveis e analisados em Mendonça (2006). 
Após, serão demonstrados os principais argumentos atinentes à posição legalista, a qual entendia como sendo a solução normal e constitucional a sucessão de Jânio Quadros pelo seu então vicepresidente, João Goulart. Tais argumentos serão aduzidos a partir da análise do manifesto do então governador do Rio Grande do Sul, Leonel Brizola, líder da Cadeia da Legalidade. ${ }^{2}$

\subsection{O discurso militar da ordem: o veto a Goulart}

O Manifesto dos ministros militares, lançado em 30 de agosto, ou seja, cinco dias após da renúncia de Jânio Quadros, representou a posição oficial dos ministros da Guerra, da Marinha e da Aeronáutica, respectivamente, o marechal Odílio Denys, o vice-almirante Sílvio Heck e o brigadeiro-do-ar Gabriel Grum Moss. Nesse sentido, a posição dos ministros foi plenamente contrária à posse de Goulart. O conteúdo do Manifesto visa a justificar a "inconveniência" de Jango assumir a Presidência da República, a partir da construção de um argumento, tido por seus enunciadores, como de cunho legal e constitucional. Dessa forma, inicia-se a análise tomando o primeiro parágrafo do referido Manifesto: ${ }^{3}$

No cumprimento de seu dever constitucional de responsáveis pela manutenção da ordem, da lei e das próprias instituições democráticas, as Forças Armadas do Brasil, através da palavra autorizada dos seus ministros, manifestam à Sua Excelência, o sr. presidente da República, como já foi amplamente divulgado, a absoluta inconveniência, na atual situação, do regresso ao país do vice-presidente, sr. João Goulart.

A primeira questão que merece relevo na introdução do "Manifesto dos ministros militares" é que a "inconveniência, na atual

2 Outros documentos referentes ao discurso legalista estão disponíveis para pesquisa. Nesse sentido, podem ser consultados o Manifesto do marechal Henrique Teixeira Lott, de 26/08/1961, o telegrama do general Machado Lopes ao ministro da Guerra, de 29/08/1961 e nota do Comando da 5a Região Militar, de 31/08/1961. Todos esses documentos estão disponíveis e analisados em Mendonça (2006).

3 O texto do Manifesto dos Ministros Militares foi extraído da obra "1961: a crise da renúncia e a solução parlamentarista” (LABAKI, 1986, p. 148-150). 
situação, do regresso ao país do vice-presidente, sr. João Goulart" é manifestada, segundo os ministros, a partir do cumprimento "constitucional", "da ordem, da lei e das próprias instituições democráticas”. Em outras palavras, conforme os signatários, eles se encontram respaldos pela legislação que lhes obriga a manter a ordem interna. A lei à qual os ministros buscam amparo é a própria Carta Constitucional de 1946, ${ }^{4}$ que, no seu artigo 177 estatui: "destinam-se as Forças Armadas a defender a Pátria e garantir os poderes constitucionais, a lei e a ordem".

Note-se que o artigo 177 da Constituição Federal está em "consonância" com o disposto no primeiro parágrafo do Manifesto em análise. Nesse sentido, os ministros, prevendo que o retorno ao Brasil e a consequiente posse do vice-presidente representaria uma ameaça ao cumprimento da lei e da ordem no país, querem assim impedi-la para que justamente a lei e a ordem sejam efetivamente mantidas e não ameaçadas. No parágrafo seguinte manifestam:

Numa inequívoca demonstração de pleno acatamento dos poderes constitucionais, aguardaram elas [as Forças Armadas], ante toda uma trama de acusações falsas e distorções propositadas, sempre em silêncio, o pronunciamento solicitado ao Congresso Nacional. Decorridos vários dias, e como sintam o desejo de maiores esclarecimentos por parte da opinião pública, a que inimigos do regime e da ordem buscam desorientar, vêm-se constrangidas agora, com a aquiescência do sr. Presidente da República, a vir ressaltar, de pública, algumas das muitas razões em que fundamentaram aquele juízo.

No parágrafo acima, os ministros militares reafirmam o pleno "acatamento dos poderes constitucionais" diante da atitude que naquele momento tomavam. Assim, eles esperaram um pronunciamento oficial do Congresso Nacional para que aquele Poder manifestasse a inconveniência do retorno de Goulart, pronunciamento que, aliás, não ocorreu. ${ }^{5}$ É de se notar que tal espera de uma atitude

4 Os artigos da Carta Constitucional de 1946 foram extraídos da obra, versão CDROM, “Textos Políticos da História do Brasil” (BONAVIDES \& AMARAL, 2002).

5 Os artigos 59, 62, 88 e 89 da Constituição Federal de 1946 estabelecem o rito para a suspensão dos poderes do presidente: "Art. 59. Compete privativamente à Câmara dos Deputados: I - a declaração, pelo voto da maioria absoluta de seus membros, 
do Congresso sustentava-se no fato de que a suspensão do chefe do executivo federal é ato constitucional de competência exclusiva do Congresso Nacional. Assim, o artigo 59, inciso I, da Constituição Federal de 1946 estatui que compete privativamente à Câmara dos Deputados, pelo voto da maioria absoluta de seus membros declarar a procedência ou não das acusações contra o Presidente da República. Declarada a procedência, passa ser de competência também privativa, desta vez do Senado Federal, nos termos do artigo 62, inciso I, o julgamento do Presidente da República em relação aos crimes de responsabilidade por ele cometidos. Os crimes de responsabilidade estão arrolados no artigo 89 da Carta Magna. Dá-se, nesse sentido, especial destaque ao parágrafo IV deste artigo, o qual estabelece como crime de responsabilidade do Presidente da República o atentado contra "a segurança interna do País", o que está, segundo o documento, em "consonância" com a preocupação dos ministros militares em relação à ordem interna mencionada no primeiro parágrafo do Manifesto. Já o artigo 88, parágrafo único, da Carta Constitucional, estatui que, uma vez declarada a procedência da acusação, fica o Presidente da República suspenso de suas funções.

Outro argumento exarado pelos ministros militares neste trecho, em relação à legalidade do veto a Goulart, é que o mesmo tinha "a aquiescência do sr. presidente da República". No momento, interinamente, exercia a Presidência da República o presidente da Câmara dos Deputados, o deputado Ranieri Mazzilli. Desta forma, segundo o Manifesto, os ministros agiam legalmente nos termos do art. 176 da Carta Constitucional conforme segue:

da procedência ou improcedência da acusação contra a Presidente da República, nos termos do art. 88, e contra os ministros de Estado, nos crimes conexos com os do Presidente da República”; "Art. 62. Compete privativamente ao Senado Federal: I - julgar o Presidente da República nos crimes nos crimes de responsabilidade e os ministros de Estado nos crimes da mesma natureza conexos com os daquele"; "Art. 88. O Presidente da República, depois que a Câmara dos Deputados, pelo voto da maioria absoluta de seus membros, declarar procedente a acusação, será submetido a julgamento perante o Supremo Tribunal Federal nos crimes comuns, ou perante o Senado Federal nos crimes de responsabilidade. Parágrafo único. Declarada a procedência da acusação, ficará o Presidente da República suspenso das suas funções”; Art. 89. São crimes de responsabilidade os atos do Presidente da República que atentarem contra a Constituição Federal e, especialmente, contra: (...) IV - a segurança interna do País" (BONAVIDES \& AMARAL, 2002). 
Art. 176. As Forças Armadas, constituídas essencialmente pelo Exército, Marinha e Aeronáutica, são instituições nacionais permanentes, organizadas com base na hierarquia e na disciplina, sob a autoridade suprema do Presidente da República e dentro dos limites da lei.

Quando os ministros mencionam que agem com a aquiescência do presidente da República, eles buscam demonstrar que estão sob sua "autoridade suprema". Além disso, "aquiescência" - que significa assentimento ou anuência - infere o sentido de delegação, de concordância com o ato (o veto a Goulart) que estava sendo tomado naquele momento pelo chefe do Executivo, a partir da ação dos ministros militares. Nesse sentido, aduz o documento que os ministros estavam duplamente amparados pela lei: por um lado, esperaram, em vão, um posicionamento prévio do Congresso Nacional no sentido da suspensão dos poderes presidenciais de João Goulart; por outro lado, não agiram de forma isolada, mas com a "aquiescência" do presidente da República em exercício, o deputado Ranieri Mazzilli.

O Manifesto tinha como argumento principal sempre a manutenção da ordem interna e o risco de que essa estaria correndo no caso da efetivação da posse de João Goulart. Para tanto, construíram nos terceiro e quarto parágrafos um breve histórico da trajetória política de Jango, visando demonstrar o perigo que o então vice-presidente apresentava à ordem interna. Significam-no como um "agitador" e ilustram tal assertiva a partir da experiência de Goulart como ministro do Trabalho no governo constitucional de Getúlio Vargas:

Já ao tempo em que exercera o cargo de ministro do Trabalho, o sr. João Goulart demonstrara, bem às claras, suas tendências ideológicas incentivando e mesmo promovendo agitações sucessivas e frequientes nos meios sindicais, com objetivos evidentemente políticos e em prejuízo mesmo dos reais interesses de nossas classes trabalhadoras. E não menos verdadeira foi a ampla infiltração que, por essa época, se processou no organismo daquele Ministério, até em pontos-chaves de sua administração, bem como nas organizações sindicais, de ativos e conhecidos agentes do comunismo internacional, além de incontáveis elementos esquerdistas. 
No trecho acima, os ministros mencionaram a passagem de Goulart no Ministério do Trabalho de Vargas e das pressões que o então presidente sofreu para a sua destituição. ${ }^{6}$ Para os militares, Goulart, "bem às claras", demonstrava ser, já em 1954, um "agitador”. Para além disso, eles atribuíram que suas tendências ideológicas comunistas persistiram ainda no período como vice-presidente da República de Quadros:

No cargo de vice-presidente, sabido é que usou sempre sua influência em animar e apoiar, mesmo ostensivamente, movimentações grevistas promovidas por conhecidos agitadores. E ainda há pouco, como representante oficial, em viagem à URSS e à China comunista, tornou clara e patente sua incontida admiração ao regime desses países exaltando o êxito das comunas populares (LABAKI, 1986, p. 149).

Neste parágrafo, os ministros de Quadros deixam claro que Goulart representa uma ameaça à ordem em função de suas ligações com o "comunismo internacional". A posse do vice-presidente representaria um período inquietador de agitações no país, razão pela qual as Forças Armadas, representadas por seus ministros, na condição de cumpridora "de seu dever constitucional de responsáveis pela manutenção da ordem, da lei e das próprias instituições democráticas", não poderiam permitir que a posse se procedesse, uma vez que, segundo seus "diagnósticos de desordem”, Goulart era o elemento central para instauração da desordem no país. Nas palavras dos ministros:

6 Em relação à destituição de Goulart, Labaki faz referência nesta passagem: "Com o retorno de Getúlio à Presidência (1951), era natural que este tivesse em seu afilhado político um fiel colaborador. Assim, em 1953, Jango foi convidado a assumir o Ministério do Trabalho. Para Getúlio parecia ser the right man in the right place. Mas a direita, em sua maioria antigetulista, via em Jango um perigoso 'demagogo sindicalista', 'admirador do justicialismo peronista', e chiou. Vargas e Goulart compraram a briga. Enfrentaram uma campanha diária de boicote e acusações. A situação tornou-se insustentável em fevereiro de 54, quando Jango defendeu um aumento de $100 \%$ no salário mínimo. Um 'Memorial de Coronéis' foi enviado a Getúlio via seu ministro da Guerra, general Ciro Cardoso. Nele, redigido pelo então tenente-coronel Golbery do Couto e Silva, 81 oficiais esbravejavam contra a 'crise de autoridade', a corrupção desenfreada e o 'comunismo solerte'. Getúlio entendeu a mensagem. Destituía Jango e o general Ciro Cardoso antes que o destituíssem” (LABAKI, 1986, p. 55-56). 
Estão as Forças Armadas profundamente convictas de que, a ser assim, teremos desencadeado no país um período inquietador de agitações sobre agitações, de tumultos e mesmo choques sangrentos nas cidades e nos campos, de subversão armada, enfim, através da qual acabarão ruindo as próprias instituições democráticas e, com elas, a justiça, a liberdade, a paz social, todos os mais altos padrões, de nossa cultura cristã.

Na Presidência da República, em regime que atribui ampla autoridade de poder pessoal ao Chefe da Nação, o sr. João Goulart constituir-se-á, sem dúvida, no mais evidente incentivo a todos aqueles que desejam ver o país mergulhado no caos, na anarquia, na luta civil. As próprias Forças Armadas, infiltradas e domesticadas, transformar-se-iam, como tem acontecido noutros países, em simples milícias comunistas.

Frise-se que o discurso dos ministros militares, seguindo-se a concepção teórica de Chantal Mouffe (2000), é antagônico em relação à posse de João Goulart, uma vez que o antagonismo é a relação que constitui, não adversários, mas inimigos. É o discurso que propugna a completa negação do outro, que impossibilita, no limite, a ação política, uma vez que a transforma numa relação de guerra, em que qualquer tipo de entendimento torna-se impossível.

No final do Manifesto, os ministros buscam sujeitos ao seu discurso de ideologia anticomunista que, em termos práticos visava o impedimento da posse de Goulart, seja pela via legal, já tida como ineficaz, seja pela via armada, a partir de um golpe de Estado. Assim, afirmam:

Arrostamos, pois, o vendaval, já esperado, das intrigas e das acusações mais despudoradas, para dizer a verdade tal como ela é, ao Congresso dos representantes do povo e, agora, ao próprio povo brasileiro.

Todo discurso é enunciador de ideologia, o qual não se apresenta de maneira transparente, uma vez que é uma leitura sobredeterminada da realidade. $\mathrm{O}$ discurso dos ministros visando impedir a posse de Goulart tinha como enunciação ideológica o fato de que Jango uma vez "ligado" ao comunismo internacional, ideologia política tida pelos ministros militares como promovedora da desordem e da falta de liberdade - deveria ser impedido de tomar posse em função desta 
sua comprometedora inclinação que resultaria "inevitavelmente" num estado de guerra e desordem absolutas. "Dizer a verdade", tal como enunciado no excerto acima, impõe a busca de adeptos a essa verdade, uma vez que, ao que transparece, existe uma mentira a ser denunciada: a de que a posse de Goulart representaria a continuidade da paz social e constitucional até então vigente no país. Tal busca da verdade, de "abrir os olhos" do país, tinha imediatamente dois endereços de persuasão: o Congresso Nacional e a população.

Fica também claro que a intenção primeira dos ministros militares foi a de "alertar" o Congresso Nacional para o perigo da "desordem". Nesse particular, sabe-se que o Congresso não aceitou diretamente a "solução militar". Não tendo o Congresso apoiado a "solução militar" desde o início da crise, os ministros de Jânio Quadros, como resposta, lançaram o presente Manifesto, buscando ampliar os sentidos e a abrangência de seu discurso ao "povo brasileiro". Isso representa a constante tentativa do discurso de incorporar mais sujeitos, buscando uma posição hegemônica no campo da discursividade. No caso específico dos ministros, eles precisavam da "legitimação popular" para que a "verdade" por eles defendida, ou seja, a afirmação de que Goulart no poder representaria um período de graves perturbações à ordem pública, fosse mantida. Se não existir condições para que a "verdade" seja apreendida pelo maior número possível de sujeitos, não haverá legitimidade para a execução dessa "verdade", ou seja, para a execução da "solução militar" que se limitava ao impedimento de Jango. Os ministros militares finalizam seu Manifesto da seguinte forma: "As Forças Armadas estão certas da compreensão do povo cristão, ordeiro e patriota do Brasil. E permanecem, serenas e decididas, na manutenção da ordem pública".

Os ministros estavam decididos a manter a “ordem pública”. Para tanto, tomariam as medidas preventivas para esse fim. Note-se, no entanto, que a manutenção da ordem implicaria necessariamente que medidas preventivas devessem ser tomadas. Medidas as quais os ministros sofreram acusação por parte de seus oponentes de que, na verdade, eles próprios estariam promovendo a desordem. Eles, invocando as Forças Armadas como se essas falassem num uníssono, eram, como o povo brasileiro, "cristãos", “ordeiros" e "patriotas”. E, 
de forma "serena" e "decidida", em nome da cristandade, da ordem e da pátria manteriam a ordem pública contra os "não cristãos", os "desordeiros" e os "não patriotas".

\subsection{O discurso legalista da ordem: Brizola e a cadeia da legalidade}

O Manifesto de Leonel Brizola, na condição de governador do Rio Grande do Sul, representou o início de um movimento efetivo de resistência à "solução militar" e pelo respeito estrito à Constituição Federal de 1946. O Manifesto, de 26 de agosto de 1961, ou seja, lançado no dia seguinte ao da renúncia de Jânio Quadros, na mesma data do Manifesto do marechal Lott. O Manifesto de Brizola, apesar de não tergiversar em qualquer momento em torno da defesa da legalidade da posse de João Goulart, menciona de forma muito genérica a "solução militar"7 que se anunciava naquele instante histórico. Ele deteve-se com mais cuidado no conteúdo do "Manifesto à Nação", exarado por Jânio Quadros no momento de sua renúncia. Inicia-se, portanto, a análise a partir da primeira parte do documento. ${ }^{8}$

Ao Rio Grande e ao Brasil.

O Governo do Estado do Rio Grande cumpre o dever que lhe cabe nesta hora grave da vida do país.

Cumpre-nos reafirmar nossa inalterável posição ao lado da Legalidade Constitucional. Não pactuamos com golpes ou violências contra

7 Brizola não faz menção direta aos ministros militares, tendo em vista que o manifesto do governador foi lançado antes do "Manifesto dos ministros militares", analisado na subseção anterior. Apesar disso, escolheu-se, neste artigo, analisar o manifesto do governador, tendo em vista de o mesmo se tratar do documento mais significativo no que tange ao discurso legalista, mormente por ter sido Brizola o principal responsável pela Cadeia da Legalidade, movimento importante na tentativa de barrar o golpe militar que se pôs em curso após a renúncia de Jânio Quadros. Evidentemente que a Cadeia da Legalidade somente teve relativo sucesso, tendo em vista a adesão do comandante do III Exército, general Machado Lopes, que deu suporte bélico importante para a luta política empreendida inicialmente por Brizola, fato que, apesar de importante, não será tratado neste trabalho. Para maiores informações a este respeito, consultar Mendonça (2006).

8 O conteúdo do "Manifesto de Leonel Brizola - 26.8.1961" foi extraído de Labaki (1986, p.151-152). 
a ordem constitucional e contra a liberdade pública. Se a atual Constituição não satisfaz, em muitos dos seus aspectos, desejamos o seu aprimoramento e não sua supressão, o que representaria uma regressão ao obscurantismo.

Brizola inicia seu Manifesto evocando o Rio Grande do Sul, seu estado natal e que naquela oportunidade governava, e o Brasil, tendo em vista fazer com que sua mensagem percorresse todo o território nacional, uma vez que seu teor interessava a todos os brasileiros. Sua primeira afirmação foi a de que seu governo cumpria seu dever no grave momento que passava o país. Na frase subsequiente, Brizola enunciou mais propriamente o dever que estava cumprindo: a reafirmação da "inalterável posição ao lado da Legalidade Constitucional”, ou seja, pela posse do vice-presidente da República, João Goulart, tendo em vista a renúncia de Jânio Quadros.

No sentido de defender a manutenção da estrita legalidade disposta na Carta de 1946, Brizola afirmou que não pactuava, não defendia "golpes", "violências" contra a "ordem constitucional" e contra a "liberdade pública”. Afirmou que se a Constituição não era adequada que fosse então alterada, mas nunca suprimida, uma vez que tal ato "representaria uma regressão ao obscurantismo".

Evidentemente que, neste último parágrafo, Brizola estava deixando subentendido que alguém estaria tentando ferir a ordem constitucional, do contrário seu discurso não faria qualquer sentido, visto que a solução constitucional - portanto meramente legal, nem política, nem militar - para a renúncia de Quadros, seria a simples investidura de Goulart no cargo presidencial vacante. $\mathrm{O}$ fato que fica claro neste início do Manifesto, contudo, desmente esta mera expectativa legal, pois estava evidente a Brizola que a ordem legal estaria sob ameaça. Continuando o documento:

A renúncia de S. Excia., o presidente Jânio Quadros, veio a surpreender a todos nós. A mensagem ${ }^{9}$ que S. Excia. dirigiu ao povo brasileiro contém graves denúncias sobre pressões de grupos, inclusive do exterior, que indispensavelmente precisam ser esclare-

9 A mensagem à qual Brizola se reporta é o "Manifesto à nação", lançado por Jânio Quadros na data de sua renúncia em 25 de agosto de 1961. 
cidas. Uma Nação que preza a sua soberania não pode se conformar pacificamente com a renúncia do seu mais alto magistrado sem uma completa elucidação desses fatos.

Nesse excerto, Brizola faz referência direta à mensagem da renúncia de Quadros. Nesta parte, o governador do Rio Grande do Sul deixa ainda mais clara sua suspeita em relação à ameaça à ordem legal manifestada no parágrafo anterior. Inicia o parágrafo afirmando que tomou como surpresa a renúncia de Jânio. Contudo, afirma a existência de "graves denúncias sobre pressões de grupos, inclusive do exterior" e defende que as mesmas "precisam ser esclarecidas", uma vez que a soberania do país depende disso. Neste ponto, Brizola chama a atenção de que o pretenso golpe que se armava poderia ter, dentre os seus articuladores inclusive estrangeiros, o que, do ponto de vista político, e mesmo jurídico, representa grave ofensa à soberania do Brasil, uma vez que somente aos nacionais cabem os destinos políticos do país. Na sequiência do documento:

A comunicação do sr. ministro apenas notifica o governo do Estado da renúncia do sr. presidente da República. Por motivo dos acontecimentos, como se impunha, o governo deste Estado dirigiu-se à S. Excia., o sr. vice-presidente da República, dr. João Goulart, pedindo o regresso urgente ao país, o que deverá ocorrer nas próximas horas.

Este ponto do Manifesto é particularmente interessante, uma vez que traz implícita a mudança do chefe de Estado. Note-se que, anteriormente, Brizola fez referência a Quadros a partir do pronome de tratamento "Sua Excelência" (S. Excia.), pois estava dirigindo-se ainda ao presidente. Contudo, nesse trecho em questão, quando trata diretamente da renúncia do presidente, Quadros passa a ser tratado simplesmente por "Senhor" (sr.), uma vez que renunciou ao cargo e deixou de ser presidente. Igualmente é tratado apenas por "sr." o ministro Pedroso Horta, que notificou o governo do Estado a renúncia de Quadros.

Note-se ainda mais um dado curioso. O governo do Estado do Rio Grande do Sul foi somente "notificado" do ato da renúncia, ou seja, em nenhum momento, conforme ressaltou Brizola, ele teve qualquer possibilidade, por exemplo, de tentar demover Quadros 
de sua renúncia que foi tida também como sendo surpreendente ao governador. Esta breve "notificação", informação, mero ato de fazer-se tomar conhecimento do ato do ex-presidente Quadros, "impôs" a Brizola o inabalável dever, "por motivo dos acontecimentos”, de dirigir-se a "S. Excia., o sr. vice-presidente da República, dr. João Goulart”, solicitando-lhe “o regresso urgente ao país”. Note-se como é dado o tratamento ao vice-presidente com os pronomes "S. Excia" e "dr", visto que Goulart era o vice-presidente legalmente investido no cargo e que sua chamada a regressar ao país era justamente para que ele assumisse, com urgência, o cargo de presidente da República. Continuando no documento:

O ambiente no Estado é de ordem. O governo do Estado, atento a essa grave urgência, vem tomando todas as medidas de sua responsabilidade, mantendo-se inclusive em contato e entendimento com as autoridades militares e federais.

Apesar do clima de ameaça de desrespeito à ordem institucional que sugere o Manifesto, Brizola afirma que, no Rio Grande do Sul, a ordem está mantida. Isso quer dizer, a legalidade está mantida no estado. Para assegurá-la, o governador mantinha contatos com autoridades militares e federais. Encerra o documento da seguinte forma:

O povo gaúcho tem imorredouras tradições de amor à Pátria comum e de defesa dos direitos humanos. E seu governo, instituído pelo voto popular - confiem os rio-grandenses e os nossos irmãos de todo o Brasil - não desmentirá estas tradições e saberá cumprir o seu dever.

Leonel Brizola

Governador do Estado.

Neste trecho final, o governador enuncia as tradições do povo gaúcho em defesa da Pátria e dos direitos humanos. Além disso, afirma que seu governo - "instituído pelo voto popular", e daí a sua legitimidade - cumprirá seu dever anunciado no início do Manifesto, ou seja, o de defender a "Legalidade Constitucional" que, em última análise, significa garantir a posse, na Presidência, de João Goulart, também eleito pelo voto popular e, portanto, legítimo de assumir o cargo em questão. 


\section{A crise e a posição inicial do parlamento brasileiro}

Na seção anterior, foram apresentados, tendo em vista o impasse gerado com a abrupta renúncia do presidente Jânio Quadros e o posterior veto dos ministros militares à posse de João Goulart, os dois principais discursos políticos em torno da crise sucessória. Neste momento, será enfocada a posição original do parlamento brasileiro em relação ao episódio em análise. Tal posição, contrária a qualquer solução diferente da constitucionalmente prevista posse do vice-presidente da República, é importante de ser aqui demonstrada, tendo em vista que a mesma será modificada no decorrer do desdobramento da crise, a partir das discussões em torno da instituição do sistema parlamentar de governo.

Desta forma, é digno de nota que a idéia da implantação do sistema parlamentarista foi debatida logo no primeiro dia após a renúncia de Quadros. Nesse sentido, os deputados presentes na 155a sessão, em 26 de agosto, em alguns momentos alternavam a discussão sobre a legalidade da posse de Goulart com a instituição do sistema parlamentarista, pois que, para alguns parlamentares, a crise política que se iniciava ocorria justamente por ser o presidencialismo um sistema instável.

Entretanto, em nenhum momento, os deputados que naquele dia pronunciaram-se em favor do parlamentarismo apontaram esse sistema político como sendo a alternativa mais adequada para a solução da situação política naquela conjuntura. Pelo contrário, a idéia dominante, tanto aos que defendiam o sistema como aos seus contrários, era a de que, somente após o término do governo de Goulart, poder-se-ia experimentar o parlamentarismo sem que sua instituição fosse tida como casuística. Do contrário, sua implantação era tida como um tipo de "solução de continuidade". Pode-se ter a clara percepção disso no debate travado pelos deputados Eloy Dutra e Paulo Freire, ${ }^{10}$ quando o primeiro sugere o sistema e o segundo contradita-o como solução ao impasse da renúncia de Jânio Quadros como abaixo segue:

10 É digno de nota que na votação da emenda parlamentarista, em segundo turno na Câmara Federal, o deputado do PSP/MG, Paulo Freire, votou favoravelmente pela instituição do sistema parlamentar de governo. 


\section{O SR ELOY DUTRA:}

(...) Acredito que a razão de toda esta crise decorre do regime presidencialista. Acredito que esta Casa deva trabalhar com afinco para que, no próximo qüinquiênio a emenda parlamentarista seja adotada e possamos, então, viver num regime livre de impactos e emoções causadas pelas renúncias ou pelo poder excessivo conferido ao Presidente da República.

(...)

O Sr. Paulo Freire - (...) nobre colega, há uma idéia por aí, a qual V. Exa já fez uma referência, creio, de se instituir o regime parlamentarista.

O SR ELOY DUTRA - a partir do próximo qüinquiênio.

O Sr. Paulo Freire - Ah bem! Porque me pareceu ouvir que devia ser instituído imediatamente. O Congresso iria dar um golpe nas instituições, na Constituição se aceitasse essa idéia infeliz de se adotar a tese parlamentarista a toque de caixa, para que o Sr. João Goulart não tomasse posse (...) (Diário da Câmara dos Deputados, 27/08/1961, p. 6221).

A questão em torno do parlamentarismo, naquele momento inicial de crise, era apenas acessória em relação a uma discussão mais ampla: a posse de Goulart. Tal posse só seria admitida sob um clima de normalidade constitucional. A instituição do parlamentarismo naquele momento, mesmo para os seus próprios defensores, era vista como um tipo de golpe com o apoio do próprio Congresso Nacional, que servia como uma espécie de "avalista legal" para dar legitimidade à quebra da ordem políticolegal pretendida pelos ministros militares. Nesse sentido, apesar de os deputados parlamentaristas pronunciarem-se em defesa do sistema, não defendiam a sua instituição num instante de crise (ou pelo menos não tinham coragem de defender o sistema parlamentar de forma enfática naquele momento).

Por outro lado, a questão fundamental que perpassava pela quase unanimidade dos pronunciamentos parlamentares era de que João Goulart deveria tomar posse com suas prerrogativas políticas asseguradas. Seja o parlamentarismo, ou outra proposta que circulava no Senado Federal de chamamento de novas eleições, desta 
vez indiretas para eleição de novo presidente ${ }^{11}$, eram medidas não admitidas pelos deputados. Nesse sentido, muito significativo foi o pronunciamento de Almino Affonso (PTB/AM) ${ }^{12}$ em 26 de agosto:

Afirma-se, por igual, que outros setores, no receio de um choque com estas áreas militares, buscariam uma acomodação em termos de fazer tramitar por esta Casa soluções jurídicas imaginosas dentro das quais se mantivesse a aparência de legalidade, mas que, ao invés, ferisse a fundo a própria instituição democrática (Diário da Câmara dos Deputados, 27/08/1961, p. 6250).

Dessa forma, nos primeiros dias da crise política, a partir dos pronunciamentos dos deputados, parecia que o Congresso Nacional efetivamente iria defender a posse de João Goulart sob a mais estrita égide legal. Contudo, a radicalização dos acontecimentos, apesar de não ter comprometido a idéia inicial de garantir a posse do vicepresidente, ajudou o parlamento brasileiro a ser mais sensível em relação a uma solução que buscasse acomodar as diferenças: uma solução, não de compromisso, mas de continuidade.

\section{A "solução de continuidade" parlamentarista: um duplo golpe contra Goulart}

A partir de agora, será analisada a discussão dos deputados em torno da proposta da emenda parlamentarista ${ }^{13}$, tendo em vista as

11 Em vários pronunciamentos, os deputados admitiam que circulavam muitos boatos acerca do momento. Um desses boatos, trazidos ao plenário pelo deputado Aurélio Vianna (PSB/AL), na 155aㅗ sessão, de 26 de agosto, dizia respeito a uma provável emenda em tramitação no Senado Federal de eleição indireta de um novo presidente da República: “(...) democracia racionada não é democracia, não vale como democracia (...). De que nos serviria uma democracia totalmente mutilada se porventura for verdadeira a notícia de que o Senado manipula uma emenda à Constituição para que a eleição do Presidente da República se processe pelo voto dos Senadores e dos Deputados Federais, dos Congressistas (...)" (Diário da Câmara dos Deputados, 27/08/1961, p. 6223).

12 O deputado Almino Affonso votou contra a aprovação em segundo turno da emenda parlamentarista.

130 foco principal das discussões sobre a emenda se deu em torno da indiscutível perda de poder que João Goulart sofreria, a partir da adoção do sistema parlamentarista, o que, por si só, seria natural em se tratando de um tipo de 
duas posições defendidas ao longo das sessões, ou seja, em favor ou contra a instituição do parlamentarismo. Inicialmente é importante destacar alguns aspectos formais acerca da proposição da emenda. Assim, em 29 de agosto, a Comissão Especial, integrada pelos deputados Afonso Celso (PSD), Djalma Marinho (UDN), Oswaldo Lima Filho (PTB) e Chagas Freitas (PSP), produziu parecer à Emenda Constitucional $n^{\circ} 16$, apresentada em 6 de julho de 1961 pelo deputado Raul Pilla (PL) e demais 235 deputados subscritores. ${ }^{14}$

A referida Comissão proferiu parecer favorável ao projeto, justificando-o a partir dos seguintes argumentos:

A instituição do sistema parlamentar que a Constituição de 1946 não adotou vem sendo tentada, desde então, por sucessivas emendas constitucionais, como é do conhecimento de toda a Nação. A República baniu o parlamentarismo dos quadros constitucionais. Há setenta anos vive o Brasil as incertezas que caracterizam, nos países de incipiente formação democrática, a experiência presidencialista. Não vale recordar os erros e equívocos que sua prática tem determinado, tais e tantos que estão, ao menos os mais recentes na memória de toda a Nação (...). A emenda constitucional do eminente Sr. Raul Pilla, subscrita por mais de dois terços da Câmara dos Deputados, (...) restaura em seu esplendor, o sistema que deu ao

sistema de governo que, segundo seus críticos, entre os juristas constitucionalistas, atribui poderes extremos ao poder legislativo, praticamente esvaziando as prerrogativas do Chefe de Estado que passa a ter grosso modo atribuições meramente de representação externa. Na direção dessa crítica, veja-se a posição de Dalmo Dallari: "O Chefe de Governo, por sua vez, é a figura política central do parlamentarismo, pois é ele que exerce o poder executivo. Como já foi assinalado, ele é apontado pelo Chefe de Estado para compor o governo e só se torna Primeiro Ministro depois de obter a aprovação do Parlamento. Por esse motivo é que muitos consideram o Chefe de Governo, no parlamentarismo, um delegado do parlamento, pois ele só pode assumir a chefia do governo e permanecer nela (...) com a aprovação da maioria parlamentar. Como assinalou Loewenstein, não há como sustentar que no parlamentarismo se preserva a separação dos poderes" (DALLARI, 1983, p. 207).

14 No parecer aparece expressamente a referência de que a emenda foi proposta por mais de dois terços dos membros da Câmara dos Deputados, uma vez que a Casa era então composta por 314 parlamentares. Como o parecer da Comissão à proposta de emenda parlamentarista foi favorável, a referência da assinatura de mais de dois terços dos parlamentares em favor da emenda serviu como mais um meio de legitimá-la e de convencer os deputados contrários à instituição do sistema. 
Império o realce e o brilho dos maiores homens públicos do Brasil em todos os tempos (Diário da Câmara dos Deputados, Suplemento ao $\mathrm{n}^{\circ} 151,166^{\underline{a}}$ sessão de $1^{\circ}$ de setembro de 1961, p. 02 ).

É interessante destacar que as justificativas produzidas pela Comissão Especial desvinculam a discussão da Emenda do contexto da crise política pela qual o Brasil atravessava. Tal desvinculação era propositada, uma vez que buscava dar um ar de "total imparcialidade" para a tomada de decisão da Câmara dos Deputados frente ao golpe que no momento se tramava no país. Nesse sentido, segundo esse raciocínio, tomar uma decisão em prol ou contra o parlamentarismo significaria a tomada de uma decisão política soberana e racional por parte dos representantes do povo, sem vinculação com qualquer ameaça à ordem instituída. Para robustecer o argumento da imparcialidade e da decisão soberana do Congresso, ao mesmo tempo em que era apresentada pela Comissão a emenda parlamentar, estava junto no "pacote" a pronta defesa da posse de João Goulart. Nesse sentido, é interessante o pronunciamento do deputado Euzébio Rocha (PDC/SP):

Sr. Presidente, o Parlamento brasileiro esteve perfeitamente à altura deste instante histórico. Tomando conhecimento, em condições de absoluta serenidade, da paixão do momento e da violência com que se erguiam contra ele, postas à serviço da fraude, nos pronunciamos de forma categórica em documento que escreve uma das mais belas páginas da vida parlamentar brasileira em que se afirmou respeito à Constituição Federal que, no caso, implica no cumprimento do seu Artigo 79, com a investidura do Sr. João Belchior Marques Goulart na Presidência da República, com os poderes que o povo lhe conferiu.

Sr. Presidente, um parlamento que assim decide tem toda autoridade para votar neste instante a emenda parlamentar (...).

Sr. Presidente, agora está provado que o momento político exige solução de equilíbrio, porque a coragem não é violência. A coragem é a capacidade de resolver os problemas da Pátria com a serenidade devida (Diário da Câmara dos Deputados, Suplemento ao n 151, p. 09).

Entretanto, o fato é que tal decisão política de extrema gravidade estava sendo tomada tendo em vista justamente às pressões externas, o que é óbvio em se tratando de uma Casa política que tem 
por característica ser sensível às pressões sociais, principalmente num momento de radicalidade política como o que o país estava passando. A prova mais clara da pressão com que o parlamento votava a emenda estava na própria alteração regimental que, às pressas, também foi produzida para se discutir a matéria. ${ }^{15}$

Lido o projeto ${ }^{16}$, os deputados passaram à discussão da matéria e logo ficou clara a constituição de dois discursos concorrentes: um em favor da emenda e o outro contrário a mesma. Em relação ao discurso favorável à aprovação da emenda $n^{\circ} 16 / 61$, os deputados produziram os seguintes argumentos: A) a defesa do parlamentarismo estava presente nos princípios e estatutos de alguns partidos; B) o Sistema Presidencialista de Governo carregava muitas incertezas e fragilidades, além de ser um sistema personalista; C) a instituição do parlamentarismo, naquele momento, evitaria uma "revolução", cujo resultado seria imprevisível; e D) o parlamentarismo servia para livrar o país da ameaça das forças do materialismo dialético.

Já em relação aos parlamentares que se opuseram à emenda, foram produzidos os seguintes argumentos: A) a instituição do sistema parlamentarista representava um claro desrespeito à Constituição Federal para satisfazer os interesses dos ministros militares; B) a aprovação do parlamentarismo representaria a falta de dignidade do parlamento brasileiro, em razão do medo do fechamento do Congresso Nacional, a partir de um golpe militar;

15 Previamente à discussão da emenda propriamente dita, discutiu-se e votou-se, em regime de urgência, em 31 de agosto, nas $163^{a}$ e $164^{a}$ sessões, o texto que ficou conhecido com "Normas de emergência" para a tramitação da emenda constitucional parlamentarista. Segundo tais normas, durante a discussão não seria possível apresentar subemendas. A própria discussão sobre os méritos do projeto teve também restringidas as orações dos deputados a dois representantes por partido em cada um dos dois turnos de discussão e votação, conforme segue: "na discussão da emenda só poderão falar dois representantes de cada partido, por quinze minutos improrrogáveis, não sendo permitida a apresentação de reposição acessória sugerindo modificá-la” (p. 6367).

16 A apresentação do projeto de emenda constitucional $n^{\circ} 16 / 61$, referente à instituição do sistema parlamentarista de governo, bem como a sua discussão no plenário da Câmara dos Deputados, se deu nas sessões n ${ }^{\circ} 166$ e 167, de $1^{\circ}$ de setembro e nas $168^{a}$ e $169^{a}$ sessões legislativas de 2 de setembro. Tais sessões estão publicadas na edição de sábado, 2 de setembro de 1961, do Diário do Congresso Nacional, no suplemento ao Diário n 151 . 
C) o parlamentarismo representava uma medida política casuística visando à limitação dos poderes de João Goulart, vice-presidente eleito pelo povo brasileiro; D) um golpe branco nas instituições e deposição de um presidente eleito; E) a emenda parlamentarista seria aprovada às pressas, sem que tivesse havido uma séria discussão acerca de um assunto de tamanha importância; F) o parlamentarismo representava o retorno ao poder dos partidos políticos que haviam perdido as últimas eleições.

Como é possível perceber, os argumentos produzidos em favor da emenda são de duas ordens. Os argumentos A e B referem-se às próprias qualidades do sistema parlamentarista. Já os argumentos C e D, correspondem ao fato de o sistema servir como uma solução à crise política instaurada a partir da renúncia de Jânio Quadros.

Assim, os argumentos A e B favoráveis ao parlamentarismo foram justificados da seguinte forma. $\mathrm{O}$ argumento $\mathrm{A}$ foi produzido por parlamentares de partidos como o PL e o PSP, os quais afirmaram que esse sistema de governo estava presente nos seus estatutos. ${ }^{17}$ Já o argumento B visava a estabelecer as vantagens desse sistema em detrimento do presidencialismo. Nesse particular, a Comissão Especial que deu parecer favorável à emenda parlamentarista, defendeu-a apresentando as "fragilidades" do regime presidencialista:

A República baniu o parlamentarismo dos quadros constitucionais. Há setenta anos vive o Brasil as incertezas que caracterizam, nos países de incipiente formação democrática, a experiência presidencialista. Não vale recordar os erros e equívocos que sua prática tem determinado, tais e tantos que estão, ao menos os mais recentes na memória de toda a Nação (p. 02).

Os argumentos B e C favoráveis ao parlamentarismo caracterizam a implantação do sistema como um elemento de uma engenha-

17 O deputado Paulo Lauro (PSP/SP) invocou o princípio parlamentarista de seu partido na 166 sessão: "Ainda agora, ao invocarmos na conjuntura atual, as normas, os princípios que marcaram as lutas do nosso Partido político, vamos encontrar, logo no pórtico de seu programa, aquela inscrição que determina a adoção do parlamentarismo, atendidas sempre as peculiaridades brasileiras, precedidas de consulta prévia ao eleitorado" (Suplemento ao $n^{\circ} 151$, de 2 de setembro de 1961, p. 10). 
ria política destinada a sanar a crise da sucessão de Quadros. O argumento B, "a instituição do parlamentarismo evitaria uma revolução, cujo resultado seria imprevisível", foi certamente o mais utilizado pelos parlamentares de todos os partidos, daí a caracterização de que se tratou de um elemento de uma complexa engenharia política visando conformar, ao mesmo tempo, os discursos "solução militar" e "solução legalista". Note-se o caráter casuístico da medida na defesa do sistema pelo deputado Ulisses Guimarães (PSD/SP): “uma razão fundamental, substancial e decisiva arrasta minha decisão e meu voto: é a razão política, porque somente através deste sistema podemos fazer com que a paz ingresse no seio da família brasileira" (Suplemento ao $\mathrm{n}^{\circ} 151$, de 2 de setembro de 1961, p. 12). Em tom ainda mais dramático argumenta Euzébio Rocha (PDC/SP):

Quero, ao aparte do nobre colega, responder conclusivamente. É hoje o Parlamento quem proclama o direito de empossar-se o Senhor João Goulart na Presidência da República. Este não é um parlamento covarde capaz de decidir sob a força das baionetas. (Palmas). Estamos decidindo, porque a conjuntura política está a demonstrar que a violência, a morte, o derramamento de sangue não convêm ao Brasil, e que o presidencialismo fracassou (Muito bem). Diante dessa prova, não podemos deixar de votar o sistema parlamentarista. A nossa coragem cívica está a ditar a solução de paz para todos os brasileiros (Suplemento ao $\mathrm{n}^{\circ}$ 151, de 2 de setembro de 1961, p. 10).

Por fim, a posição D em favor da aprovação da emenda tinha como argumento o fato de que a instituição do novo sistema impediria a presença de elementos marxistas no governo. Este argumento notadamente tinha um caráter que se coadunava com a vontade dos ministros militares, pois que estava baseado na mesma apreensão: a de que a investida de Goulart na Presidência da República, sob a égide do sistema presidencialista, representaria a emergência de elementos do comunismo internacional e que transformaria o Brasil numa república sindicalista, sem paz nem ordem interna. Em defesa da proposição D, veja-se a manifestação do deputado Rubem Nogueira (PSD/BA):

Sr. Presidente, Srs. Deputados, vamos votar a emenda parlamentarista para reintroduzir a nossa Pátria na legalidade constitucional, restabelecer a tranquiilidade dos espíritos, repor o nosso País no álveo do 
progresso e da civilização cristã, nesta hora ameaçada pelas obscuras forças do materialismo dialético e histórico (Muito bem; muito bem. Palmas) (Suplemento ao $\mathrm{n}^{\circ} 151$, de 2 de setembro de 1961, p. 11).

Já a posição política dos parlamentares que se pronunciaram contrariamente ao sistema foi dividida basicamente em três linhas argumentativas. A primeira delas, representadas pelas assertivas A, B, C e D, justificava que a instituição do sistema representaria grosso modo um golpe nas instituições políticas e legais vigentes. A assertiva $\mathrm{E}$ representa a reclamação de parlamentares sobre o fato de que o sistema parlamentarista seria aprovado sem a necessária discussão a uma medida de tão drástica alteração no funcionamento político-institucional brasileiro. A assertiva $\mathrm{F}$ denunciava que o parlamentarismo representaria o retorno ao poder da elite política que governou o país até antes da eleição de Quadros.

Dessa forma, as assertivas A, B C e D foram as mais comuns entre os críticos da implantação sistema. As idéias que essas assertivas trazem basicamente são as de "golpe", "desrespeito à Constituição", "impedimento do presidente constitucionalmente eleito". Nesse sentido, é interessante retomar o texto da assertiva A: "a instituição do sistema parlamentarista representava um claro desrespeito à Constituição Federal para satisfazer os interesses dos ministros militares". Esta assertiva foi insistentemente pronunciada pelos parlamentares contrários ao parlamentarismo, como, por exemplo, o deputado Giordano Alves (PTB/RS):

A opinião pública, que está ao lado da legalidade, já não admite - desejo trazer, para orientação de meus pares esta manifestação espontânea e generalizada da população brasileira - qualquer arranhão, qualquer alteração no sistema institucional do País, na Constituição atual para, sob pressão, sob coação, nos submetermos a um imperativo ditado por alguns que hoje procuram subverter a ordem do País e impor aqui o regime extralegal (Suplemento ao $\mathrm{n}^{\circ}$ 151, de 2 de setembro de 1961, p. 03).

As assertivas B, C e D representam justamente a consequiência da adoção do parlamentarismo para satisfazer a vontade dos ministros militares. Neste particular, é interessante mencionar 
que a assertiva $\mathrm{B}^{18}$, ou seja, a "aprovação do parlamentarismo representaria a falta de dignidade do parlamento brasileiro por medo desse ser fechado", significaria a conivência do Congresso com a ação golpista, pois a aprovação da Emenda pelo Legislativo daria uma aparência de legalidade ao que, na verdade, conforme a assertiva $\mathrm{D}^{19}$, seria um verdadeiro golpe branco nas instituições políticas e institucionais brasileiras, uma vez que, de acordo com a assertiva $\mathrm{C},{ }^{20}$ o parlamentarismo representava, naquele momento, uma medida política casuística visando à limitação dos poderes de João Goulart.

Outro argumento contrário à aprovação da Emenda parlamentarista está expresso no enunciado E, refletindo o fato de que a aprovação da mesma seria feita às pressas, sem que houvesse uma discussão mais aprofundada da matéria. Nesse sentido, independentemente de qualquer uma das duas posições assumidas pelos parlamentares, já foi mencionada a alteração no Regimento da Câmara dos Deputados que permitiu a discussão, em caráter de urgência, da emenda. É interessante lembrar, como estava disposto na referida alteração, que as discussões sobre a matéria, em primeiro e em segundo turno, deveriam ser feitas por

18 Em relação ao enunciado $B$, tome-se como exemplo novamente as palavras do deputado Giordano Alves (PTB/RS): "Sr. Presidente, não podemos, por um preço qualquer, procurar manter aberto este Congresso. O que precisamos é, a qualquer preço, isto sim - defender a dignidade do Parlamento brasileiro. Incorreríamos no erro de incompatibilizarmos o Congresso Nacional com a opinião pública, com a consciência generalizada do povo livre do Brasil, transigindo em nosso direito constitucional" extralegal (Suplemento ao $n^{\circ} 151$, de 2 de setembro de 1961, p. 03).

19 Para exemplificar o enunciado $D$, será tomado um excerto do pronunciamento do deputado Aurélio Vianna (PSB/AL) na declaração partidária indicando o voto contrário à emenda: "só uma coisa se explica: foi deposto pelo Parlamento, se isto for aprovado, um Presidente da República. Isto é o que fica. Houve um golpe branco nas instituições" (Suplemento ao $n^{\circ} 151$, de 2 de setembro de 1961, p. 12).

20 Em relação ao enunciado $C$, veja-se a manifestação do deputado Floriceno Paixão (PTB/RS): "reiterando, pois, meus pontos de vista aqui expendidos no início da semana, quero dizer que jamais receberá meu voto qualquer proposição que tenha sido ou vier a ser apresentada nesta Casa, com o objetivo de limitar as do Presidente da República, Dr. João Goulart, sob a égide do regime presidencialista” (Suplemento ao ${ }^{\circ} 151$, de 2 de setembro de 1961, p. 05). 
somente dois parlamentares de cada partido por apenas quinze minutos e sem direito a apartes. ${ }^{21}$

Além disso, a emenda em si não foi debatida pelos parlamentares, tendo em vista que ela propriamente não foi o palco principal das discussões dos mesmos. $\mathrm{O}$ instituto do parlamentarismo representava, naquele contexto, tanto para os contrários como principalmente para os seus defensores, uma medida para solucionar o impasse político decorrente da renúncia de Jânio Quadros. Na leitura dos Anais das discussões em plenário, raríssimas vezes foram mencionados ou discutidos pontos da proposta, artigos ou incisos específicos, tendo em vista que ela própria não era o mais importante no debate. Ficou claro também que muitos parlamentares nem conheciam o texto da proposta com a profundidade que uma discussão nesse nível mereceria. Nas palavras do deputado Aurélio Vianna (PSB/AL), buscando discutir dispositivos específicos do projeto e sendo apartado pelo deputado Bagueira Leal (UDN/ES):

O SR. AURÉLIO VIANNA:

\section{(...)}

[lê parte do projeto da emenda parlamentarista]

"A Câmara dos Deputados, na primeira sessão e pela maioria dos presentes, exprimirá sua confiança no Conselho de Ministros. A recusa da confiança importa a formação de um novo Conselho de Ministros" [fim da leitura].

Mas se estes não tiverem o apoio da Câmara, não forem por ela considerados dignos de dirigir a Nação isso por três vezes e se merecer o Conselho de Ministros já organizado um voto de desconfiança do Parlamento, que acontecerá? Completando três votos de desconfiança, então a Câmara será dissolvida.

21 A oposição à emenda reclamou muito do novo regimento de discussão da matéria aprovado. Nas palavras do deputado federal Aurélio Vianna (PSB/AL): "Dois Deputados por partido podem usar a palavra por quinze minutos para discutir emenda ao diploma maior do País. Que o povo anote isto. Em $15 \mathrm{mi}$ nutos ninguém pode ler esta emenda, votada às pressas, velozmente, porque para alguns o tempo urge, o tempo corre, a Nação está em perigo e a emenda poderá salvá-la, ou prendê-la, quem sabe?" (Suplemento ao $n^{\circ} 151$, de 2 de setembro de 1961, p. 05). 
O Sr. Bagueira Leal - Não ...

O Sr. Aurélio Vianna - É verdade, V. Exa. não leu. Vou ler. É o art 13. Ninguém está lendo coisa nenhuma num assunto dessa natureza. Afirmei porque li. Ouça o nobre deputado:

[novamente lê parte do projeto da emenda parlamentarista] "Verificada a impossibilidade de constituir-se o Conselho de Ministros por falta de apoio parlamentar, comprovada em consecutivas moções de desconfiança opostas a três Conselhos, o Presidente da República poderá dissolver a Câmara dos Deputados, convocando novas eleições que se realizarão no prazo máximo de noventa dias" [fim da leitura] (Suplemento ao $\mathrm{n}^{\circ} 151$, de 2 de setembro de 1961, p. 11).

A questão, portanto, era solucionar o impasse gerado entre os partidários dos discursos "solução militar" e "solução legalista". O parlamentarismo foi a solução encontrada por aqueles sujeitos que formaram uma posição denominada "solução de continuidade".

Como último argumento contrário à emenda parlamentarista tem-se o enunciado F: "o parlamentarismo representava o retorno ao poder dos partidos políticos que haviam perdido as últimas eleições". Significativo a esse enunciado foi o pronunciamento do deputado Barbosa Lima Sobrinho (PSB/PE):

Mas quero dizer à Câmara com toda a franqueza que eu preferiria (...) uma atitude de resistência. Todos esses que andam por aí a exaltar a coragem da Câmara amanhã terão de admitir que a Câmara para resolver a situação - como se diz aqui - reconhece o direito do Sr. João Goulart a quê? A outro mandato. O Sr. João Goulart teria direito ao mandato que resultou das urnas, ao mandato que resultou da Carta de 46, mas o que Câmara lhe quer entregar é um mandato diverso, que venha a permitir a outros partidos a chegada ao poder influindo mais nos destinos da República.

Subverte-se, assim, o resultado das urnas, porque os partidos que nelas triunfaram vão ser pouco a pouco afastados, pouco a pouco colocados em segundo ou terceiro plano, para prevalecerem aqueles que, tendo de certo maior capacidade política nas manobras de bastidores ou de pronunciamentos nas Câmaras Legislativas, conseguirão chegar de novo ao poder, através de outros processos que não apenas os das urnas livres, afastando aqueles outros que não tenham a mesma habilidade, a mesma capacidade política e a mesma expressão nas manifestações partidárias. 
Eis aí, Sr. Presidente, o outro aspecto pitoresco desse momento que estamos vivendo. É uma subversão do resultado das urnas. É a negação do pleito de 3 de outubro. Porque, na verdade, os partidos triunfantes passam aqui, se não a partidos perdedores, pelo menos a partidos secundários para que os partidos derrotados se tornem, na verdade, os partidos vencedores (Suplemento ao $\mathrm{n}^{\circ} 151$, de 2 de setembro de 1961, p. 13).

Esse argumento é particularmente importante, pois infere a intenção de partidos, como principalmente o PSD, de retornar ao poder do Estado, após a derrota de Lott para Quadros nas eleições presidenciais. Esse retorno seria francamente possibilitado pela alteração do sistema político, tendo em vista que é muito comum no sistema parlamentarista que o gabinete do primeiro-ministro busque a maioria parlamentar no Congresso para que seu governo obtenha o indispensável apoio para efetivamente governar. ${ }^{22}$

\section{Considerações finais: os três discursos em perspec- tiva e a "solução de continuidade" como a confirma- ção do golpe contra Goulart}

Neste trabalho, foram apresentados, tendo em vista o impasse gerado com a abrupta renúncia do presidente Jânio Quadros e o posterior veto dos ministros militares à posse de João Goulart, os dois principais discursos políticos em torno da crise sucessória. Neste momento, serão sistematizadas as conclusões acerca do episódio. Para isso, inicialmente é importante retomar os elementos essenciais dos três discursos do período - "discurso militar", "discurso legalista" e "solução de continuidade" - caracterizados a partir dos seus "diagnósticos de desordem" e de suas "soluções de ordem".

O discurso militar foi originalmente articulado pelos três ministros militares e obteve apoio de algumas lideranças civis, como

22 O gabinete do primeiro primeiro-ministro, Tancredo Neves (PSD/MG) não fugiu à tradição do gabinete ser formado pela maioria parlamentar do partido majoritário. A composição das forças partidárias ficou assim disposta: PSD, primeiro-ministro e 5 ministérios; PTB, 2 ministérios; UDN e PDC, um ministério cada (LABAKI, 1986, p. 131). 
o governador da Guanabara, Carlos Lacerda ${ }^{23}$, o presidente da República em exercício, o deputado federal Ranieri Mazzilli e alguns poucos membros do parlamento nacional. Tal discurso significava como "diagnóstico de desordem" a própria posse do vice-presidente eleito João Goulart em substituição ao demissionário Jânio Quadros. Argumentavam seus próceres, para tanto, que o Brasil, num governo de Jango, necessariamente ficaria marcado por um período de extrema instabilidade política. Além disso, havia ainda a ameaça da instituição de uma república sindical ou comunista. Como "solução de ordem" seus líderes defendiam que era necessário, por um lado, que o Congresso Nacional declarasse o impedimento de Goulart, por motivos de segurança nacional, e, por outro lado, que fossem realizadas novas eleições presidenciais.

O discurso legalista foi deflagrado e liderado pelo então governador do Rio Grande do Sul, Leonel Brizola, e teve como fundamentais aliados, num primeiro momento, o comandante do III Exército, general Machado Lopes e a maioria dos membros do Congresso Nacional. Contou ainda com o apoio maciço de setores da sociedade civil, sindicatos, igrejas, movimentos sociais. Significava como "diagnóstico de desordem" o veto militar à investidura de João Goulart na Presidência. Como "solução de ordem" defendia a simples posse de Goulart como presidente da República, tendo em vista estar expressamente estatuído na Constituição Federal de 1946 que o vice-presidente deveria assumir a Presidência no caso da vacância do cargo pelo seu titular.

23 Não foi analisado nenhum documento produzido por Carlos Lacerda. Contudo, é notório o seu envolvimento e sua defesa do discurso militar à solução do impasse gerado pela renúncia de Quadros. Diariamente, os deputados federais defensores do "discurso legalista" denunciavam na tribuna da Câmara Federal atos autoritários e repressores da polícia da Guanabara ordenados por Lacerda. A esse respeito, Argelina Figueiredo escreve: "O Estado da Guanabara testemunhou a mais dura repressão em razão do apoio de seu governador aos ministros militares. Contrariando a disposição geral da nação, o governador da Guanabara, Carlos Lacerda, era a única liderança política expressiva a sustentar, e mesmo a incitar, a intervenção militar. Afinado com o padrão de raciocínio relativo à democracia alimentado pela 'Banda de Música' da UDN, Lacerda divulgou uma nota criticando o 'formalismo' dos defensores da Constituição (...)" (FIGUEIREDO, 1993, p. 42-43). 
O último discurso constituído foi o da "solução de continuidade". Foi constituído inicialmente no Congresso Nacional como tentativa de encontrar uma solução à crise político-militar instaurada ("diagnóstico de desordem"). A instituição do sistema parlamentarista de governo foi a "solução de ordem", proposta que efetivamente triunfou ao final do episódio. Resgatados os três principais discursos concorrentes no período, seguem-se as conclusões acerca da crise e de sua solução.

Como visto no início deste trabalho, existe uma unanimidade entre os cientistas sociais de que efetivamente um golpe militar, em 1961, resultou fracassado. Notadamente, existe um pensamento hegemônico de que uma "solução de compromisso", promovida pelas forças conservadoras que dominavam o Congresso Nacional, impediu o golpe e Goulart, enfim, pôde assumir a Presidência num regime parlamentarista. Em contrario sensu, será agora apresentada outra interpretação acerca do episódio.

Neste sentido, inicialmente, afirma-se aqui claramente que um golpe civil-militar obteve pleno sucesso em $1961^{24}$. Tal afirmação está baseada no tipo de solução dada à crise sucessória, a qual, se não pode ser taxada plenamente de ilegal, pode inequivocamente ser vista como casuística e, portanto, estranha ao status quo ante, estipulado pela Constituição Federal de 1946.

É comum a afirmação de que a simples posse de Goulart foi suficiente e necessária para se ter evitado um golpe eminentemente militar. Essa afirmação parte do princípio de que os ministros mili-

$24 \mathrm{O}$ deputado Almino Affonso, posteriormente, publicou obra dedicada à análise deste momento conturbado da vida política nacional e de seus reflexos no curto interregno parlamentarista. Na condição de uma das principais lideranças do PTB ao tempo da crise decorrente da renúncia de Jânio Quadros, Affonso denunciou, conforme já apontado, na mesma linha de argumentação deste artigo, o "golpe branco" que estava em curso com a aprovação da emenda parlamentarista. Seu livro, rico em documentos, possui uma passagem que parece apropriada de ser aqui reproduzida. Tal passagem refere-se à correspondência encaminhada por esse líder parlamentar ao então vice-presidente João Goulart, em 30 de agosto de 1961, a seguir: "O parlamentarismo, agora, é 'golpe branco' das forças reacionárias. É o mesmo 'golpe', em termos civis, que os militares tentaram dar. É eminentemente de sentido reacionário. Não significa apenas um veto ao seu nome. É o veto a todos que se proponham a defender as teses que correspondem hoje aos interesses do povo" (AFFONSO, 1988, p. 41). 
tares que buscaram vetar a posse de Goulart, ao final do episódio, efetivamente não conseguiram tal intento, uma vez que Jango foi efetivamente empossado. Contudo, a questão a colocar-se é a seguinte: Goulart assumiu a Presidência da República a que preço? É interessante notar que o preço pago por Goulart não é tido como relevante para os analistas. Contudo, ele é fundamental, pois o golpe que foi intentado e que obteve sucesso não foi somente contra João Goulart, mas também contra uma posição política de esquerda que lhe dava suporte naquele momento e que, tanto os militares como a maioria conservadora do Congresso Nacional, não queriam a mesma instalada na estrutura do Estado brasileiro.

Ademais, não há o menor indício de que originalmente os ministros militares desejavam eles próprios assumir o controle do Estado. O que eles não queriam era simplesmente Goulart no poder, pois, segundo eles, seu governo representaria um momento de caos político e de infiltração de lideranças comunistas. Esse objetivo, se analisado o resultado da crise, foi plenamente alcançado com a instituição do sistema parlamentarista.

Para tentar satisfazer as pretensões de Goulart e de seus sustentadores - o que de fato não foi possível com o arranjo político resultante - foi entregue a Jango um cargo de presidente num sistema parlamentarista, o qual lhe reservava infinitamente menos prerrogativas das que lhe eram antes asseguradas no sistema presidencialista com a sua vitória eleitoral em três de outubro de 1960. Para os ministros militares, portanto, apesar do desgaste sofrido com a crise, seu intento foi plenamente alcançado: foi retirado o poder de Goulart e da esquerda brasileira: estava, assim, o Brasil livre da "ameaça comunista".

$\mathrm{O}$ argumento que mais comumente justifica a instituição do parlamentarismo é o da tentativa de uma "solução de consenso", ou de "compromisso", que acabou por evitar uma guerra civil que efetivamente poderia ter ocorrido. Para isso, o Congresso Nacional jogou um papel preponderante na proposição e na aprovação da emenda parlamentar. Contudo, para além dessa "atitude patriótica", uma maioria parlamentar, mormente pessedista, tinha muito interesse na situação provocada pelos ministros militares, pois com a eleição de Jânio Quadros, havia sido retirada do poder e via no parlamentarismo a possibilidade de encurtar o tempo de seu retorno. 
O trabalho dessa maioria foi simplesmente o de convencer os ministros militares de que Goulart no poder com um sistema parlamentarista era o mesmo do que Goulart deposto, com a vantagem de não haver qualquer desgaste com uma acusação de golpe. Além disso, formar-se-ia, como efetivamente ocorreu, um governo de coalizão entre as forças mais conservadoras do Congresso que barraria, acrescida já de uma maioria parlamentar que daria sustentação ao chefe de Governo, qualquer avanço das esquerdas no país. E assim se fez. Sob o comando do PSD, Tancredo Neves assumiu como primeiro-ministro.

Nesse sentido, utilizou-se neste trabalho a noção de "solução de continuidade", ao contrário de interpretações que privilegiam argumentos em direção de um pretenso consenso ou mesmo de um compromisso estipulado entre as partes. Frise-se: não houve qualquer compromisso entre nenhuma das partes que efetivamente deveriam selar algum tipo de compromisso. O que ocorreu, na verdade, foi uma aliança conjuntural entre os ministros militares e o Congresso Nacional de maioria conservadora. Goulart e a esquerda ficaram totalmente isolados, inclusive do ponto de vista militar, pois quando a solução parlamentarista foi aprovada, inclusive Machado Lopes, comandante do III Exército rebelde, retirou seu apoio às pretensões de Brizola de manter o sistema presidencialista mesmo à força.

Assim, pode-se afirmar que a democracia não era efetivamente um discurso valorizado entre os sujeitos políticos em disputa, pois as regras do jogo foram mudadas casuisticamente. Se, por um lado, as pretensões iniciais dos ministros militares não foram satisfeitas, tendo em vista uma flagrante falta de apoio político, por outro lado, a normalidade democrática, que só se justificaria com a posse de Goulart num regime presidencialista, também não obteve o indispensável apoio das forças políticas mais conservadoras do Congresso Nacional, que conseguiram convencer e se coligar com os ministros militares numa clara trama que redundou num golpe civil-militar.

Sete de setembro de 1961 foi a data da posse de João Goulart como presidente da República, mas também a data de um exitoso golpe civil-militar contra as instituições democráticas brasileiras. Isolado, como um rei sem súditos, o líder trabalhista assumiu a Presidência da República num regime parlamentarista. 
Levou quinze meses para deslindar o golpe branco, a "solução de continuidade" a qual foi vítima. O contra-golpe do plebiscito do sistema de governo iria lhe devolver suas justas prerrogativas constitucionais em mais uma manobra casuística da política brasileira, quando novamente e de forma extemporânea, volta à cena política o sistema presidencialista de governo.

Recebido em 27.3.2008 Aprovado em 30.11.2008

\section{Referências}

AFFONSO, A. Raízes do golpe: da crise da legalidade ao parlamentarismo (1961-1963). São Paulo: Marco Zero, 1988.

BONAVIDES, P. \& AMARAL, R. Textos políticos da história do Brasil. (Volumes VII e IX). Brasília: Senado Federal, 2002. [CD ROM].

DALLARI, D. Elementos de teoria geral do estado. 10 $10^{\mathrm{a}}$ ed. São Paulo: Saraiva, 1983.

DREIFUSS, René Armand. 1964 a conquista do estado: ação política, poder e golpe de classe. Petrópolis: Vozes, 1981.

FIGUEIREDO, A. Democracia ou reformas? Alternativas democráticas à crise política (1961-1964). São Paulo: Paz e Terra, 1993.

LABAKI, A. 1961: a crise da renúncia e a solução parlamentarista. São Paulo: Brasiliense, 1986.

MENDONÇA, D. Democracia sem democratas: uma análise da crise política no governo João Goulart (1961-1964). 2 Vol. 2006. Tese (Programa de Pós-Graduação em Ciência Política) - Universidade Federal do Rio Grande do Sul, Porto Alegre.

MOUFFE, C. The democratic paradox. London: Verso, 2000.

SKIDMORE, T. Politics in Brazil, 1930-1964: an experiment in democracy. Oxford, Oxford University, 1967.

SANTOS, W. G. 0 cálculo do conflito: estabilidade e crise na política brasileira. Belo Horizonte/Rio de Janeiro: UFMG/IUPERJ, 2003. 


\begin{abstract}
The civil-military coup of 1961: critique of hegemonic explanations.

The present article presents a critical perspective of the hegemonic interpretation which sustains that in 1961, after Jânio Quadro renounced, there was a frustrated attempt at a military coup, demonstrated by the fact that João Goulart was then able to assume the presidency. We argue that what in fact occurred was a civil-military coup in which the nation's Congress took part.
\end{abstract}

Keywords: 1961 coup, João Goulart, Brazilian National Congress. 